\title{
A Protocol for Producing Virus-Free Artichoke Genetic Resources for Conservation, Breeding, and Production
}

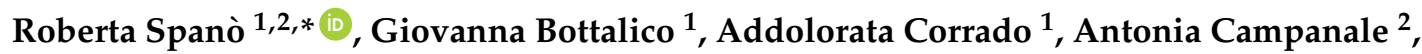 \\ Alessandra Di Franco ${ }^{1}$ and Tiziana Mascia ${ }^{1,2}$ \\ 1 Dipartimento di Scienze del Suolo della Pianta e degli Alimenti, Università degli Studi di Bari "Aldo Moro", \\ Via Amendola 165/A, 70126 Bari, Italy; giovanna.bottalico@uniba.it (G.B.); corrado.ada82@gmail.com (A.C.); \\ alessandrarosari.difranco@uniba.it (A.D.F.); tiziana.mascia@uniba.it (T.M.) \\ 2 Istituto per la Protezione Sostenibile delle Piante (IPSP), CNR, UOS Bari, Via Amendola 122/D, 70126 Bari, \\ Italy; antonia.camapnale@ipsp.cnr.it \\ * Correspondence: roberta.spano@ipsp.cnr.it; Tel.: +39-080-544-3086
}

Received: 30 January 2018; Accepted: 27 February 2018; Published: 1 March 2018

\begin{abstract}
The potential of the globe artichoke biodiversity in the Mediterranean area is enormous but at risk of genetic erosion because only a limited number of varieties are vegetatively propagated and grown. In Apulia (southern Italy), the Regional Government launched specific actions to rescue and preserve biodiversity of woody and vegetable crops in the framework of the Rural Development Program. Many globe artichoke ecotypes have remained neglected and unnoticed for a long time and have been progressively eroded by several causes, which include a poor phytosanitary status. Sanitation of such ecotypes from infections of vascular fungi and viruses may be a solution for their ex situ conservation and multiplication in nursery plants in conformity to the current EU Directives 93/61/CEE and 93/62/CEE that enforce nursery productions of virus-free and true-to-type certified stocks. Five Apulian ecotypes, Bianco di Taranto, Francesina, Locale di Mola, Verde di Putignano and Violetto di Putignano, were sanitized from artichoke Italian latent virus (AILV), artichoke latent virus (ArLV) and tomato infectious chlorosis virus (TICV) by meristem-tip culture and in vitro thermotherapy through a limited number of subcultures to reduce the risk of "pastel variants" induction of and loss of earliness. A total of 25 virus-free primary sources were obtained and conserved ex situ in a nursery.
\end{abstract}

Keywords: artichoke; ecotype; virus-sanitation; meristem-tip culture; thermotherapy

\section{Introduction}

Globe artichoke (Cynara cardunculus L. var. scolymus) is a species native to the Mediterranean basin that is gaining commercial interest for its dietary and pharmaceutical value. Out of the Mediterranean area, production occurs also in the Middle East, North Africa, South America, United States, and China.

Italy is the leading world producer of globe artichoke and probably hosts the most abundant in situ diversity of the species. Apulia (southern Italy) (Figure 1) accounts for 33\% of the total Italian production estimated at 470,000 tons (FAOSTAT 2011) and harbors many artichoke varieties representing an inestimable source of germplasm [1-5]. Most of the germplasm has remained neglected and unnoticed for a long time and has been progressively eroded by several causes [6], which include a poor phytosanitary status [7]. This condition stalled until the Apulian Regional Government launched two specific actions in the framework of the 2007-2013 Rural Development Program (RDP): action 214/3 "Protection of biodiversity" and action 214/4 "Integrated projects and regional biodiversity system". Both the actions were aimed at identifying, rescuing and preserving biodiversity of woody 
and vegetable crops grown in rural areas of the Region. Globe artichoke was included in the list as one of the vegetable species recognized at risk of genetic erosion.

Compared with the abundance and diversity of the ecotypes available, only a limited number of varieties are grown in Apulia, which is, by itself, indicative of genetic erosion. Most of the ecotypes probably belong to the same genetic background but their name derived from the place where they were traditionally cultivated.

Globe artichoke is grouped as early-flowering or late-flowering type based on the time the capitula appear. Early-flowering types cluster with the "early Mediterranean group" and produce capitula between autumn and early spring, if water is supplied to dormant underground shoots and buds during summer. Conversely, late-flowering types produce capitula during spring and early summer. Despite the recent introduction of new variety types propagated by seeds, vegetative propagation through shoots and buds remains the preferred method for the new plantings of traditional globe artichoke varieties.

Implementation of globe artichoke propagation material with unknown phytosanitary status has led to the transmission and accumulation in the same plant of threatening pathogens such as vascular fungi and viruses for which no efficient control measures are available [7]. Over time, severe production losses and reduced quality have led to the shifting of crops from the south of the Bari area to the north of the region, in the Foggia province (Figure 1). However, since the material used for the new plants was infected by the vascular fungus Verticillium dahliae and by symptomless viruses these pathogens were simply transferred to the new growing areas with transitory and poor benefits to the globe artichoke market. The virome (sensu [8]) of globe artichoke may be unexpectedly complex as it includes at least 25 virus species in 10 taxonomic families that adversely affect both quality and productivity of the crop (Table 1). Some of the viruses are widespread whereas others are endemic of the Mediterranean area and frequently asymptomatic in globe artichoke. Additionally, nothing is known about viruses infecting globe artichoke at subliminal levels or viral sequences embedded in the host genome, which are the newly recognized components of plant virome [8-10].

While the abundant in situ biodiversity of globe artichoke represents an invaluable genetic resource for breeders, industry, and consumers, at the same time, it is imperative to find a way to restore and maintain a sanitary status compatible with the conservation of such biodiversity. Plant nurseries offer a solution for the ex situ maintenance and provision of virus-free planting material to farmers and breeders because the current EU Directives 93/61/CEE and 93/62/CEE enforce nursery productions to be based on virus-free and true-to-type certified stocks.

Here we describe a sanitation protocol based on the combination of in vitro meristem-tip culture and thermotherapy for the production and the ex situ conservation of virus-free propagation material of five local varieties of globe artichoke, relevant to the Apulian RDP and in conformity to the EU Directives 93/61/CEE and 93/62/CEE. 
Table 1. Viruses infecting globe artichoke in nature: taxonomic allocation, epidemiology, and disease symptoms.

\begin{tabular}{|c|c|c|c|}
\hline Viruses with Isometric Particles & Genus Family & Vector/Mode of Transmission & Disease Symptoms \\
\hline $\begin{array}{l}\text { artichoke Aegean ringspot virus } \\
\text { (AARSV) }\end{array}$ & $\begin{array}{c}\text { Nepovirus } \\
\text { (Subgroup A) Comoviridae }\end{array}$ & unknown & Yellow blotches and mild mottling. Often symptomless \\
\hline $\begin{array}{l}\text { artichoke Italian latent virus } \\
\qquad\left(\text { AILV) }{ }^{1}\right.\end{array}$ & $\begin{array}{l}\text { Nepovirus } \\
\text { (Subgroup B) } \\
\text { Comoviridae }\end{array}$ & $\begin{array}{c}\text { Longidorus apulus } \\
\text { L. fasciatus } \\
\text { Seed coat and expanded cotyledons }\end{array}$ & Mostly symptomless; patchy chlorotic stunting observed in some cvs \\
\hline $\begin{array}{l}\text { artichoke mottled crinkle virus } \\
\qquad(\mathrm{AMCV})^{1}\end{array}$ & $\begin{array}{l}\text { Tombusvirus } \\
\text { Tombusviridae }\end{array}$ & $\begin{array}{l}\text { Contact } \\
\text { Soil-borne }\end{array}$ & $\begin{array}{l}\text { Severe deformations, mottling and crinkling of the leaves. Severe distortion of } \\
\text { flower capitula. Plant death. New foliage emerging from underground buds } \\
\text { develops poorly and often shows bright chrome-yellow discoloration }\end{array}$ \\
\hline $\begin{array}{l}\text { artichoke yellow ringspot virus } \\
\text { (AYRSV) }\end{array}$ & $\begin{array}{l}\text { Nepovirus } \\
\text { (Subgroup C) } \\
\text { Comoviridae }\end{array}$ & $\begin{array}{l}\text { Pollen and seed transmission in } \\
\text { tobacco and onion }\end{array}$ & Bright yellow blotches, ringspots and line patterns sometime followed by necrosis \\
\hline $\begin{array}{l}\text { artichoke vein banding virus } \\
\text { (AVBV) }\end{array}$ & $\begin{array}{l}\text { Cheravirus } \\
\text { Secoviridae }\end{array}$ & unknown & Chlorotic discolorations along the leaf veins \\
\hline broad bean wilt virus (BBWV) ${ }^{1}$ & $\begin{array}{l}\text { Fabavirus } \\
\text { Comoviridae }\end{array}$ & $\begin{array}{l}\text { Capitophorus horni and other aphid } \\
\text { species }\end{array}$ & Yellow mottle, mosaic, or line patterns \\
\hline cucumber mosaic virus $(\mathrm{CMV})^{1}$ & $\begin{array}{l}\text { Cucumovirus } \\
\text { Bromoviridae }\end{array}$ & several aphid species & $\begin{array}{l}\text { Probably symptomless. Usually found in mixed infection with ArLV and/or } \\
\text { TSWV in plants showing severe stunting }\end{array}$ \\
\hline $\begin{array}{l}\text { pelargonium zonate spot virus } \\
\text { (PZSV) }^{1}\end{array}$ & $\begin{array}{l}\text { Anulavirus } \\
\text { Bromoviridae }\end{array}$ & several thrips species & $\begin{array}{c}\text { Moderate stunting and leaf chlorotic mottling. Chlorotic spots and line patterns } \\
\text { after inoculation under experimental conditions }\end{array}$ \\
\hline tobacco streak virus (TSV) & $\begin{array}{l}\text { Ilarvirus } \\
\text { (Subgroup 1) } \\
\text { Bromoviridae }\end{array}$ & several thrips species & Stunting and leaf deformation \\
\hline tomato black ring virus (TBRV) & $\begin{array}{l}\text { Nepovirus } \\
\text { (Subgroup B) } \\
\text { Comoviridae }\end{array}$ & Longidorus attenuatus & Mild leaf mottling \\
\hline $\begin{array}{l}\text { Viruses with Rod-Shaped } \\
\text { Particles }\end{array}$ & Genus Family & Vector/Mode of Transmission & Disease Symptoms \\
\hline tobacco mosaic virus (TMV) ${ }^{1}$ & Tobamovirus & contact & symptomless \\
\hline tobacco rattle virus (TRV) & Tobravirus & $\begin{array}{l}\text { Thrichodorus } \\
\text { Christiei }\end{array}$ & Leaf bright yellow discoloration \\
\hline
\end{tabular}


Table 1. Cont

\begin{tabular}{|c|c|c|c|}
\hline Viruses with Isometric Particles & Genus Family & Vector/Mode of Transmission & Disease Symptoms \\
\hline $\begin{array}{l}\text { Viruses with Filamentous } \\
\text { Particles }\end{array}$ & Genus Family & Vector/Mode of Transmission & Disease Symptoms \\
\hline $\begin{array}{l}\text { artichoke curly dwarf virus } \\
\text { (ACDV) }\end{array}$ & $\begin{array}{l}\text { Potexvirus } \\
\text { Flexiviridae }\end{array}$ & unknown & $\begin{array}{l}\begin{array}{l}\text { Stunting, leaf distortion and extended vein necrosis, delay in the development o } \\
\text { flower capitula }\end{array}\end{array}$ \\
\hline $\begin{array}{l}\text { Artichoke degeneration virus } \\
\text { (ADV). Putative potyvirus }\end{array}$ & Non-classified & unknown & Leaf mottling curling and crinkling \\
\hline Artichoke latent virus (ArLV) ${ }^{1}$ & $\begin{array}{l}\text { Macluravirus } \\
\text { Potyviridae }\end{array}$ & $\begin{array}{l}\text { Myzus persicae, Brachycaudus cardui, } \\
\text { Aphis fabae }\end{array}$ & Symptomless \\
\hline artichoke latent $\mathrm{M}$ virus (ArLMV) & $\begin{array}{l}\text { Carlavirus } \\
\text { Flexiviridae }\end{array}$ & unknown & Symptomless. Often in mixed infection with AILV, ArLV, AMCV \\
\hline artichoke latent $\mathrm{S}$ virus (ArLSV) & $\begin{array}{l}\text { Carlavirus } \\
\text { Flexiviridae }\end{array}$ & aphids & Symptomless \\
\hline $\begin{array}{c}\text { bean yellow mosaic virus (BYMV) } \\
1\end{array}$ & $\begin{array}{l}\text { Potyvirus } \\
\text { Potyviridae }\end{array}$ & several aphid species & Leaf yellowing, yellow flacking, line patterns, often in mixed infection with ArLV \\
\hline $\begin{array}{l}\text { Filamentous viruses and globe } \\
\text { artichoke disease }\end{array}$ & unknown & unknown & $\begin{array}{c}\text { Foliar mottling, leaf deformation and crinkling, stunting, and decreased yield. } \\
\text { Progressive degeneration }\end{array}$ \\
\hline potato virus $\mathrm{X}(\mathrm{PVX})^{1}$ & $\begin{array}{c}\text { Potexvirus } \\
\text { Flexiviridae }\end{array}$ & unknown & Mosaic, leaf deformation and narrowing, stunting \\
\hline ranunculus latent virus (RaLV) & & & Mostly symptomless. Often in mixed infection with cynara 42 virus (Cy42) \\
\hline turnip mosaic virus (TuMV) ${ }^{1}$ & $\begin{array}{c}\text { Potyviridae } \\
\text { Potyvirus }\end{array}$ & several aphid species & Symptomless. Often in mixed infection with ArLV \\
\hline $\begin{array}{l}\text { tomato infectious chlorosis virus } \\
\text { (TICV) }^{1}\end{array}$ & $\begin{array}{c}\text { Crinivirus } \\
\text { Closteroviridae } \\
\end{array}$ & Trialeurodes vaporariorum & Symptomless or mild interveinal yellowing \\
\hline Unnamed putative carlavirus & Non-classified & unknown & Symptomless \\
\hline $\begin{array}{l}\text { Viruses with Enveloped } \\
\text { Particles }\end{array}$ & Genus Family & Vector/Mode of Transmission & Disease Symptoms \\
\hline $\begin{array}{l}\text { cynara virus }(\mathrm{CraV}) \text {. Putative } \\
\text { cytorhabdovirus }\end{array}$ & $\begin{array}{l}\text { unassigned } \\
\text { Rhabdoviridae }\end{array}$ & unknown & Progressive degeneration. Often in mixed infection with AILV, ArLV, BBW, BYMV \\
\hline$\underset{1}{\text { tomato spotted wilt virus (TSWV) }}$ & $\begin{array}{l}\text { Tospovirus } \\
\text { Bunyaviridae }\end{array}$ & several thrips species & $\begin{array}{l}\text { severe stunting and deformation, generalized chlorosis and bronzing of the apica } \\
\text { leaves, distortion of the head stalk, and necrosis of portions of the inner and outer } \\
\text { scales }\end{array}$ \\
\hline
\end{tabular}




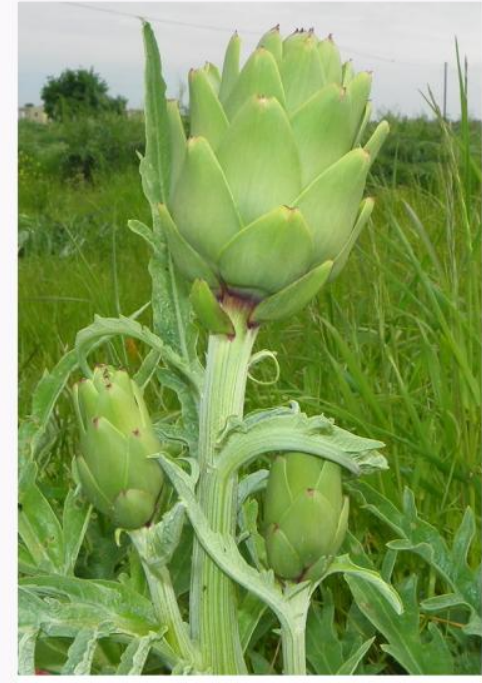

(a)

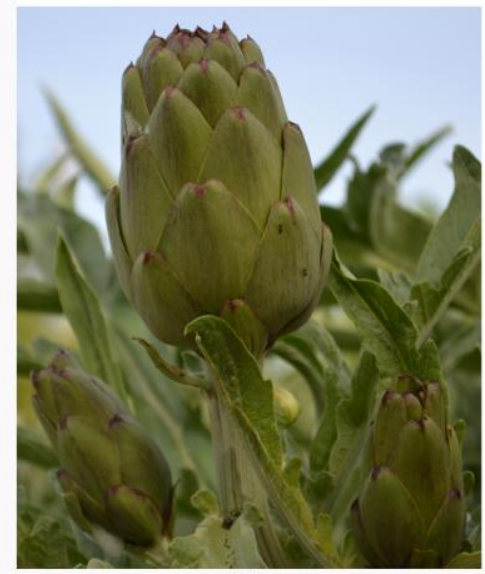

(d)

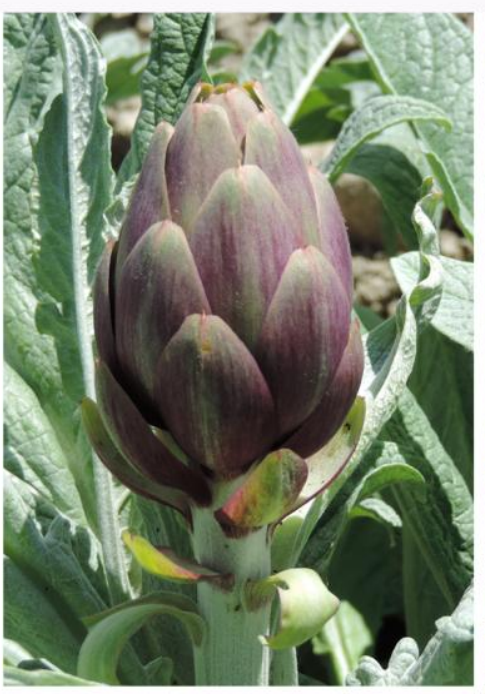

(b)

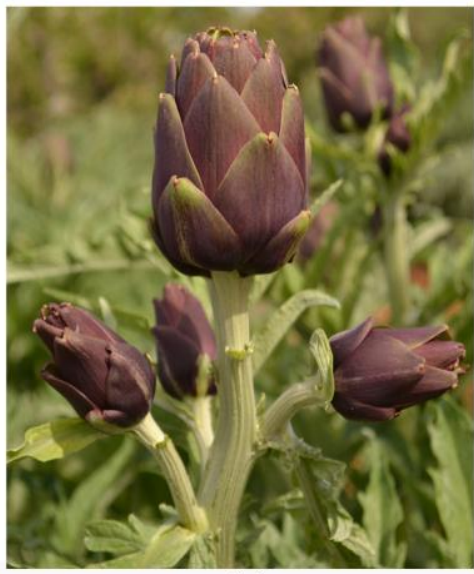

(e)

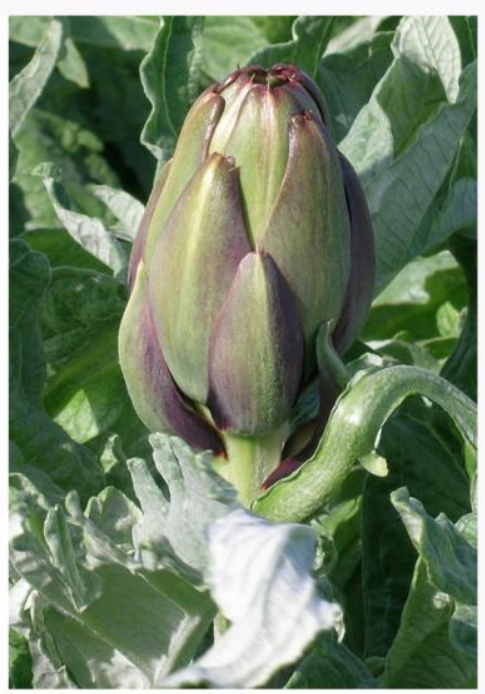

(c)

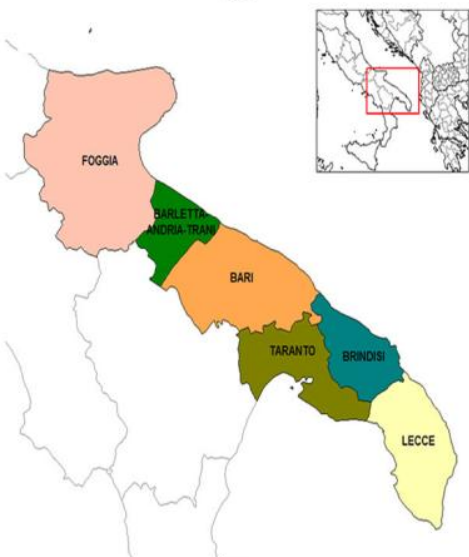

(f)

Figure 1. Apulian artichoke ecotypes subjected to sanitation from virus infection by meristem-tip and thermotherapy (a) "Bianco di Taranto"; (b) "Francesina"; (c) "Locale di Mola"; (d) "Verde di Putignano"; (e) "Violetto di Putignano"; (f) Map of province sub-areas of Apulia region. (Photo $(\mathbf{a}, \mathbf{b}, \mathbf{d}, \mathbf{e})$ courtesy of Dr. Gabriella Sonnante, CNR IBBR collection, Bari, Italy; photo (c), courtesy of Prof. Pietro Santamaria, University of Bari Aldo Moro, Bari, Italy).

\section{Materials and Methods}

\subsection{Plant Material and Assessment of the Sanitary Status}

Offshoots of the Apulian early-flowering artichoke ecotypes "Francesina" (synonym "Violetto di Brindisi", "Violetto di San Ferdinando") "Verde di Putignano", "Violetto di Putignano" and "Locale di Mola" and of the late-flowering ecotype "Bianco di Taranto" (Figure 1) were collected from local farmers and maintained in a commercial nursery Plant as "standard initial material". Offshoots were tested for the presence of the following artichoke viruses considered economically relevant by the Directive 447-03/08/12 of the Apulian Regional Government (Table 1): artichoke Italian latent virus (AILV); artichoke latent virus (ArLV); artichoke mottled crinkle virus, (AMCV); bean yellow mosaic virus (BYMV); cucumber mosaic virus (CMV); pelargonium zonate spot virus (PZSV); tomato infectious chlorosis virus (TICV); tobacco mosaic virus (TMV); tomato spotted wilt virus (TSWV) and turnip mosaic virus (TuMV). Tests were carried out by dot-blot hybridization following the protocol of Minutillo et al. [11]. Chemiluminescent signals derived from the Digoxigenin-labelled DNA probes 
were acquired by exposing the membrane under a Chemi-Doc apparatus (Bio-Rad) and analyzed with Quantity One software (Bio-Rad).

\subsection{Plant Sanitation Protocol}

Young offshoots $(10-15 \mathrm{~cm})$ were collected from symptomless plants of each artichoke ecotype grown in situ by local farmers and transplanted into pots to be maintained ex situ in the nursery. Five shoots of each ecotype were used for the sanitation protocol (Figure 2). Each shoot was washed with tap water, disinfected with a $20 \%[v / v]$ of a commercial bleach solution ( $40 \mathrm{~g} \cdot \mathrm{L}^{-1}$ active chlorine) for $20 \mathrm{~min}$, and then washed three times with sterile distilled water under a laminar flow hood.

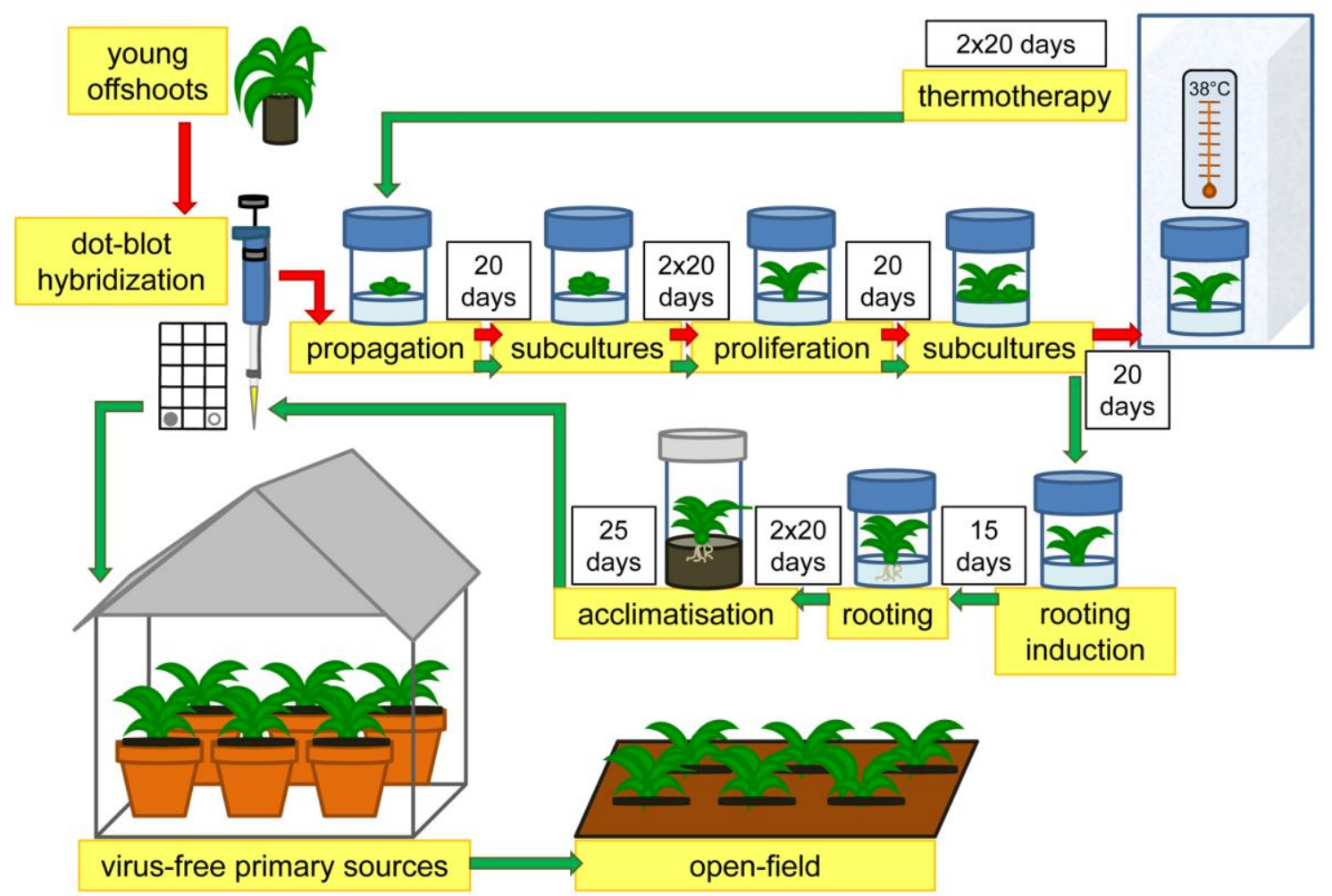

Figure 2. Schematic representation of sanitation workflow to produce virus-free artichoke plants using in vitro meristem-tip culture combined with thermotherapy. Red arrows indicate the workflow of sanitation protocol performed on young offshoots collected from farmers until thermotherapeutic treatment. Green arrows indicate the workflow of sanitation protocol performed after thermotherapy treatment.

Shoot meristem-tips $(0.2-0.4 \mathrm{~mm})$ were excised under a stereomicroscope and cultured into $60 \mathrm{~mL}$ polystyrene containers with $10 \mathrm{~mL}$ of propagation medium 1 (PM1), $\mathrm{pH} 5.8$, consisting of a basal medium (BM) supplemented with $4.9 \mu \mathrm{M} \gamma \cdot \gamma$ dimethylallilminopurine (2ip), $2.8 \mu \mathrm{M}$ gibberellic acid (GA3), $5.7 \mu \mathrm{M}$ indoleacetic acid (IAA) and MS vitamins [12], to set up appropriate in vitro conditions [13]. The BM contained MS macronutrients, NN micronutrients [14], $68 \mu \mathrm{M}$ Fe-EDTA, $2 \%[w / v]$ sucrose and $0.7 \%[w / v]$ agar.

Shoot meristem-tips were incubated at $24 \pm 1{ }^{\circ} \mathrm{C}$ in a growth chamber with a 16-h light photoperiod at 4000 lx LED light intensity. Viable shoots were transferred to fresh PM1 at 20-day intervals. After three sub-cultures on PM1, young shoots $(2-3 \mathrm{~cm})$ were transferred into $200 \mathrm{~mL}$ glass culture vessels with $30 \mathrm{~mL}$ of proliferation medium 2 (PM2) containing BM, $0.46 \mu \mathrm{M}$ Kinetin, $0.5 \mu \mathrm{M}$ 1-naphthaleneacetic acid (NAA), Z4 vitamins [15], $5.6 \mathrm{mM}$ ascorbic acid and $5.2 \mathrm{mM}$ citric acid. 
After two sub-cultures, lateral young shoots were transferred to PM1 and exposed at $38 \pm 1{ }^{\circ} \mathrm{C}$ for two cycles of 20-days each, in a growth chamber with a 16-h light photoperiod at $5000 \mathrm{~lx}$ cool light intensity.

After thermotherapy, shoot meristem-tips were excised from explants that survived treatment and sub-cultured again on PM1 and PM2, as described above. Young shoots (3-4 cm) were transferred to $200 \mathrm{~mL}$ glass culture vessels containing $30 \mathrm{~mL}$ of rooting induction medium 1 (RM1), containing BM, $55.5 \mu \mathrm{M}$ myo-inositol, $0.3 \mu \mathrm{M}$ thiamine $\mathrm{HCl}, 0.4 \mathrm{mM}$ adenine sulfate and $14.7 \mu \mathrm{M}$ indole-3-butyric acid (IBA). After 15-day induction on RM1, rhizogenesis was obtained by transferring shoots on rooting medium 2 (RM2), containing BM supplemented with $55.5 \mu \mathrm{M}$ myo-inositol, $0.3 \mu \mathrm{M}$ thiamine $\mathrm{HCl}$ and $57 \mu$ M IAA.

The rooted micro-rosettes were transplanted to pre-compressed peat disks (Jiffy- $7^{\circledR}$ pellet) soaked with a solution of $7.4 \mu \mathrm{M}$ IBA and grown at $23 \pm 1{ }^{\circ} \mathrm{C}$ in an acclimatization room with 16-h light photoperiod at 3000 lx LED light intensity. Over the 20-25 days of the acclimatization phase, relative humidity (RH) was gradually reduced from $85-90 \%$ to $55-60 \%$. Acclimatized plants were transferred to a greenhouse and grown at $18-20{ }^{\circ} \mathrm{C}, 55-60 \% \mathrm{RH}$ and $16-\mathrm{h}$ cool light photoperiod.

Plants grown in the greenhouse were tested for virus presence by dot-blot hybridization, as described above and by reverse-transcription polymerase chain reaction (RT-PCR) using primer pairs and protocols described by Minutillo et al. [11]. Virus-free clones were transferred to the nursery to set up a collection of virus-free "primary sources" (Figure 3). After six months maintenance and multiplication in the nursery Plant, primary sources were checked again for virus presence by dot-blot hybridization.

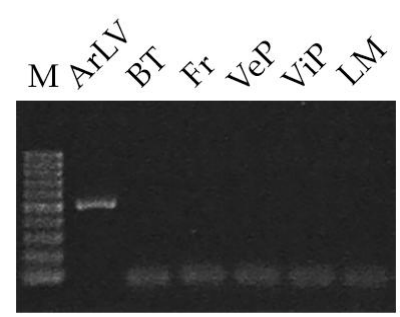

(a)

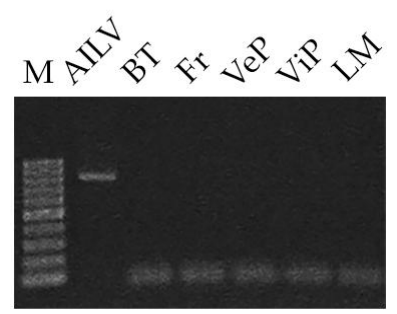

(b)

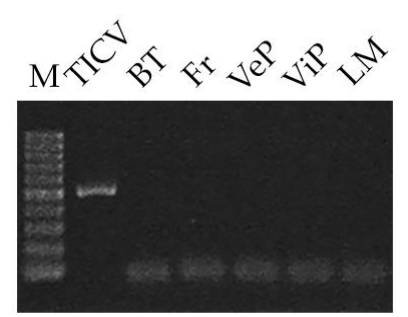

(c)

Figure 3. RT-PCR performed with primer pairs specific for (a) ArLV; (b) AILV and (c) TICV on nucleic acid extracted from primary sources of the five ecotypes of globe artichoke (BT, Bianco di Taranto; Fr, Francesina; VeP, Verde di Putignano; ViP, Violetto di Putignano; LM, Locale di Mola).

\section{Results}

Results from dot blot hybridization revealed that only the offshoots collected from the ecotype "Francesina" did not harbor infection of any of the viruses tested, while the other ecotypes considered in this study had single or mixed infections by ArLV, AILV and TICV (Table 2). Nonetheless, all the ecotypes were included in the sanitation protocol. Only $36 \%$ of the young offshoots derived from meristem tips were stabilized in vitro. The rest of the stock became contaminated by fungi, which had not been removed by the sterilization procedure.

After two cycles of sub-culture in PM2 the number of explants increased with a multiplication rate (MR) ranging from 2.8 to 7 with a mean value of $3.74 \pm 1.8$, allowing the obtaining of a sufficient number of shoots to enter the next phase of in vitro thermotherapy. Some of the explants died during the treatment while an average of $75 \%$ of micro-rosettes survived and entered the second cycle of meristem-tip culture. During the second cycle the number of explants increased with a multiplication rate (MR) that was very similar to the MR recorded in the first phase of the sanitation protocol and mostly similar among the ecotypes tested. On the contrary, rooting capacity (RC) was extremely variable (Table 2). There was an inverse relationship between MR and RC as to a higher MR corresponded a reduced RC. This problem was partially resolved by the addition of $14.7 \mu \mathrm{M}$ IBA in RM1 followed by $57 \mu \mathrm{M}$ IAA in RM2 that gave acceptable root and shoot regeneration for all 
the ecotypes. In our study, the ecotype "Verde di Putignano" showed the highest RC $(89.7 \%)$ and a MR of only 2.7. Conversely, the ecotype "Locale di Mola" had the highest MR (7) and a RC of $15.4 \%$. The ecotypes "Bianco di Taranto" and "Violetto di Putignano" showed intermediate results while the ecotype and Francesina had the, lowest RC (Table 2).

Finally, our results showed that plant survival during acclimatization phase was clearly affected by the robustness of the radical apparatus. Eighty-five percent of the rooted plants acclimatized successfully, whereas only $10 \%$ of the poorly rooted or unrooted plants were able to survive in greenhouse conditions. After the completion of sanitation protocol and acclimatization (Figure 2), we obtained a total of 25 primary sources (Table 2) that resulted virus-free when tested by dot blot hybridization and RT-PCR (Figure 3). This condition was maintained after a six-month culture and multiplication in the nursery when all the plants were checked again (Figure 4). After multiplication the number of primary sourced raised to 361 plants of Bianco di Taranto, 273 plants of Violetto di Putignano, 78 plants of Verde di Putignano, 69 plants of Francesina and 98 plants of Locale di Mola.

Table 2. Viruses detected in the off-shoots of globe artichoke ecotypes collected from farmers and their multiplication rates $(\mathrm{MR})$ and rooting capacity $(\mathrm{RC})$ obtained during the sanitation protocol.

\begin{tabular}{|c|c|c|c|c|c|c|}
\hline Ecotype & $\begin{array}{c}\text { Standard } \\
\text { Material }^{1}\end{array}$ & $\begin{array}{c}\text { Virus } \\
\text { Detected }^{2}\end{array}$ & $\begin{array}{c}\text { Stabilized } \\
\text { Shoots }^{3}\end{array}$ & $\mathrm{MR}^{4}$ & $\mathrm{RC}^{5}$ & $\begin{array}{l}\text { Primary } \\
\text { Sources }\end{array}$ \\
\hline Bianco di Taranto & 5 & ArLV & 3 & 2.8 & $68.9 \%$ & 6 \\
\hline Francesina & 5 & - & 1 & 3 & $12.5 \%$ & 1 \\
\hline Verde di Putignano & 5 & TICV & 2 & 2.7 & $89.7 \%$ & 9 \\
\hline Violetto di Putignano & 5 & TICV & 1 & 3.2 & $63.6 \%$ & 7 \\
\hline Locale di Mola & 5 & ArLV, AILV & 2 & 7 & $15.4 \%$ & 2 \\
\hline
\end{tabular}

${ }^{1}$ Number of initial offshoots of each ecotype that entered the sanitation protocol; ${ }^{2}$ Viruses detected by Dot-blot hybridization in each offshoot of standard material; ${ }^{3}$ Number of shoots obtained after three sub-culture cycles in PM1; ${ }^{4}$ MR after two sub-culture cycles in PM2; ${ }^{5}$ RC after two sub-culture cycles in RM2; ${ }^{6}$ Total number of primary sources obtained for each ecotype at the end of the sanitation protocol.

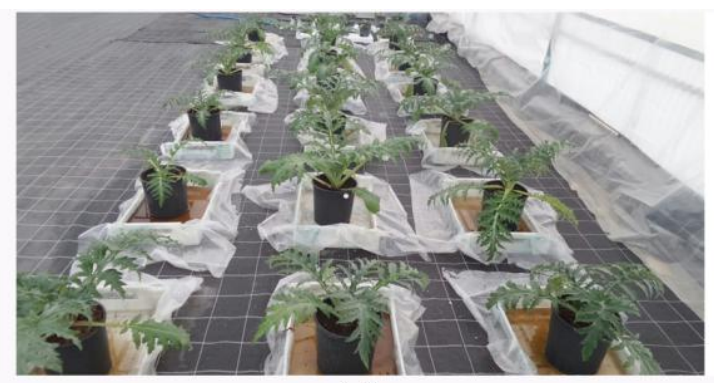

(a)

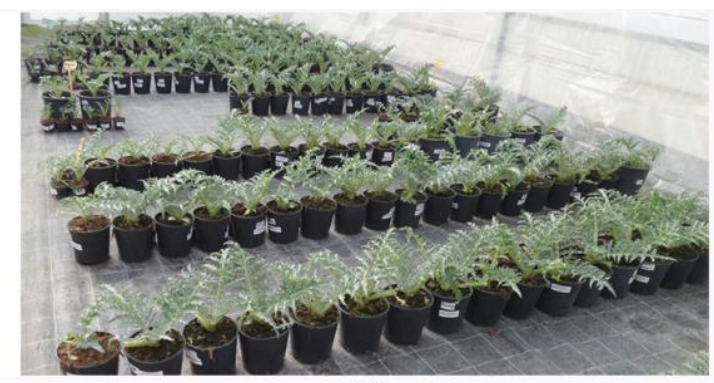

(b)

Figure 4. (a) Virus-free primary sources of the five ecotypes of globe artichoke maintained in the nursery "F.lli Corrado S.r.L." Greenhouse lateral openings and doors are protected with aphid-proof screens to preserve the phytosanitary condition obtained with the sanitation protocol; (b) Clonal in vivo multiplication of primary sources.

\section{Discussion}

The detection of mixed infections in symptomless artichoke plants confirmed that the selection of offshoots from these plants for vegetative multiplication does not guarantee the absence of virus infections. The occurrence of TICV infection in the two varieties collected from the Putignano area in the province of Bari is relevant from the eco-epidemiological point of view (Figure 1). TICV is an emerging pathogen $[16,17]$ transmitted semi-persistently by the whitefly Trialeurodes vaporariorum, but not by Bemisia tabaci. Previous investigations in Italy detected TICV in tomato and globe artichoke in Liguria, Sardinia, Latium, Campania, and Sicily. Artichoke plants infected by TICV did not show 
clear symptoms or, at most, they showed interveinal yellowing of the leaves but in all instances, plants were infested with high populations of T. vaporariorum $[18,19]$ that ensured transmission of the virus to other susceptible crops. In Apulia, the virus was recorded for the first time in mixed infection with TSWV in a tomato greenhouse in the Lecce province [20] and a second time in 2015 in another tomato greenhouse in the Bari province [21]. Interestingly, the two ecotypes "Violetto di Putignano" and "Verde di Putignano" infected by TICV were grown in the same area of the Bari province and infections may have been the result of intense fluctuations of T. vaporariorum, which are very common. Such symptomless artichoke plants escape roguing and may act as perennial TICV reservoirs from where populations of $T$. vaporariorum can acquire the virus and cause outbreaks on tomato.

The sanitation protocol was applied to all the offshoots collected. During the experimental procedure, we identified three critical steps. The first critical phase was the in vitro stabilization of meristem-tips cut from the young offshoots because only $36 \%$ of them were stabilized in vitro and used for the culture. The high rate of contamination observed were probably due to vascular fungi localized internally. This initial loss of explants was offset by a high multiplication rate that was considered satisfactory and in the range of 3.7-4.8 new shoots per explant obtained in other studies ([22] and references quoted therein). Based on previous experience [23], we did not proceed with further subcultures to reduce the risk for the induction of "pastel variants" and loss of earliness [24] for the early-flowering ecotypes.

Generally, in vitro thermotherapy is the second critical step, but compared to previous experience [23] a higher rate of micro-rosettes survived to the treatment and produced new shoots suitable for the second cycle of meristem-tip culture. This was probably due to the more stringent control of light, temperature, and RH parameters in comparison to the equipment and facilities used in the previous study. Thermotherapy proved to be an essential step to eradicate plant viruses owing to their uneven distribution in plant tissues and to the notion that some viruses may also colonize meristem-tips [25-28]. Virus localization in meristem-tips seems particularly pertinent to nepoviruses [29] and to AILV among the viruses infecting globe artichoke [30]. A markedly enhanced virus eradication by the combined action of meristem-tip culture and thermotherapy was also reported in other instances $[28,31,32]$.

The third critical step was the induction of root formation. It was reported that MR and RC require different auxin/cytokinin ratios. High ratios of auxin/cytokinin promote root regeneration, while high ratios of cytokinin/auxin stimulate shoot regeneration [33]. In our tests, a substantially balanced of auxin/cytokinin in PM1 and PM2 produced a satisfactory rate of root and shoot regeneration for all the ecotypes. López-Pérez and Martínez [22] observed a higher root induction rate of globe artichoke when a high concentration of IBA in the culture medium associated with 5 days of darkness was used to induce the rhizogenesis. In our conditions a high auxin concentration in RM steps favored rhizogenesis whereas 5 days of darkness did not induce any ameliorative effect. Benoit and Ducreux [34] and Morzadec and Hourmant [35] reported the process of root induction to be also highly dependent from the ecotype and may range from 1 to $92 \%$.

The application of the sanitation protocol allowed the obtaining of a sufficient number of virus-free primary resources to be used for nursery activity. These were increased 50-fold after one year of rapid multiplication in the nursery plant. Only the ecotype Verde di Putignano increased 9-fold. The results confirmed those of a previous study, i.e., that the combined action of meristem-tip culture and thermotherapy is required to eliminate also the infection of AILV, which localizes in the meristem-tip through which it is probably transmitted to seeds $[30,36]$.

\section{Conclusions}

Regional ecotypes of globe artichoke represent a valuable genetic resource that need adequate handling and protection. This study confirmed that some of such ecotypes harbor virus infections that may have contributed to their progressive degeneration and abandonment. The sanitation protocol had a more balanced auxin/citokinin ratio and better standardized parameters for in vitro growing and 
thermotherapy compared to that used for the reflowering type Brindisino [23]. We did not evaluate the effect of sanitation on the earliness or other agronomic traits of the ecotypes sanitized with a dedicated experimental field design, but a very preliminary small-scale field test shows promising results (Figure 5).

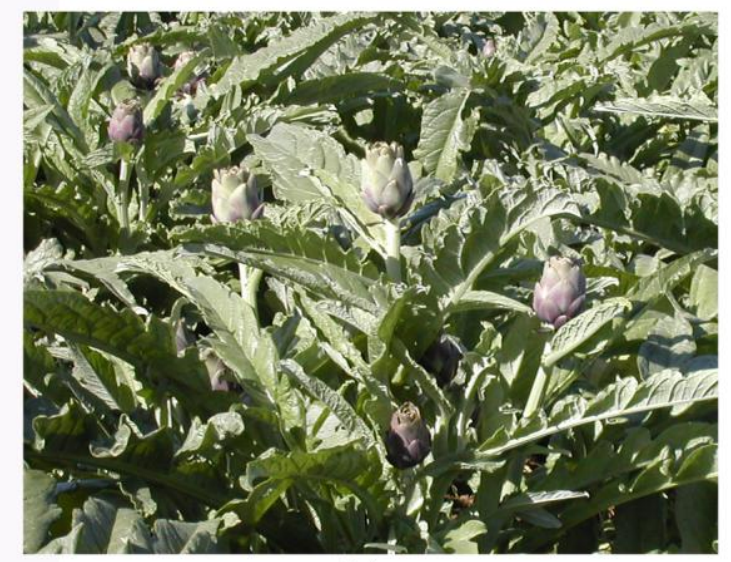

(a)

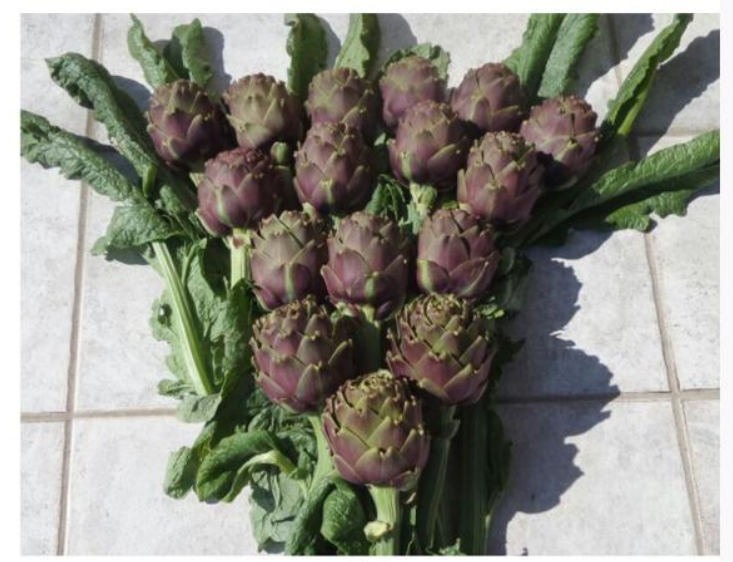

(b)

Figure 5. Production of sanitized clones of ecotypes "Locale di Mola" (a) and "Violetto di Putignano"

(b) in a small-scale experimental field for a preliminary evaluation of agronomic traits after sanitation.

The keystone to conservation of such ecotypes relies on the maintenance of the phytosanitary status obtained with sanitation. In situ maintenance would be ideal to preserve the ecological niche but it is a matter of fact that if exposed to field condition the sanitized material will undergo reinfection quickly. The reflowering type Brindisino showed an estimated ArLV reinfection rate between $1 \%$ and $2 \%$ after 2 years from planting close to a standard artichoke field with ArLV incidence higher than $80 \%$ [7].

Therefore, sanitized stocks must be maintained ex situ in nursery structures adequately protected to prevent reinfection and must be subjected periodically to phytosanitary controls.

Available diagnostics possess sufficient sensitivity and specificity to detect even subliminal infections provided that the etiologic agent is known. We already briefly addressed the issue of the complexity of plant viromes that is emerging from the application of NGS technology. Besides the biological significance, the discovery of a previously undescribed virus species in asymptomatic plants will impact quarantine regulations and issues for the virus-free certified stocks [37-40]. This issue must be addressed to fulfill expectations from the conservation and use of agricultural biodiversity and genetic resources [41]. It is expected that the use of sanitized ecotypes supplied by nursery-certified stocks and cultivated in open field for no more than two years should decrease inoculum potential and will ensure genetic resources for conservation, breeding and production.

Acknowledgments: This work was supported by the Regional Apulian project "Biodiversity of Apulian vegetable species" CE n. 1698/2005-Programma di Sviluppo Rurale per la Puglia 2007-2013. Misura 214-Azione 4 Sub azione a): "Progetti integrati per la biodiversità" grant CUP H98B13000000005, Italy. We acknowledge Donato Gallitelli, University of Bari aldo Moro, for critically reading the manuscript and Giovanni Corrado, Nursery Plant Vivaio F.lli Corrado S.r.L., Torre S. Susanna (BR), Italy for collecting and maintaining ex situ the artichoke ecotypes used in this study.

Author Contributions: R.S., G.B. and T.M. conceived and designed the experiments; R.S., A.Co. and A.Ca. performed the experiments; R.S., A.D.F. and G.B. analyzed the data; R.S. and T.M. wrote the paper.

Conflicts of Interest: The authors declare no conflict of interest. The founding sponsors had no role in the design of the study; in the collection, analyses, or interpretation of data; in the writing of the manuscript, and in the decision to publish the results. 


\section{References}

1. Romani, A.; Pinelli, P.; Cantini, C.; Cimato, A.; Heimler, D. Characterization of Violetto di Toscana, a typical Italian variety of artichoke (Cynara scolymus L.). Food Chem. 2006, 95, 221-225. [CrossRef]

2. Mauro, R.P.; Portis, E.; Acquadro, A.; Lombardo, S.; Mauromicale, G.; Lanteri, S. Genetic diversity of globe artichoke landraces from Sicilian small-holdings: Implications for evolution and domestication of the species. Conserv. Gene 2009, 10, 431-440. [CrossRef]

3. Mauro, R.P.; Portis, E.; Lanteri, S.; Mauromicale, G. Genotypic and bio-agronomical characterization of an early Sicilian landrace of globe artichoke. Euphytica 2012, 186, 357-366. [CrossRef]

4. Ciancolini, A.; Rey, N.A.; Pagnotta, M.A.; Crinò, P. Characterization of Italian spring globe artichoke germplasm: Morphological and molecular profiles. Euphytica 2012, 186, 433-443. [CrossRef]

5. Tavazza, R.; Lucioli, A.; Benelli, C.; Giorgi, D.; D'Aloisio, E.; Papacchioli, V. Cryopreservation in artichoke: Towards a phytosanitary qualified germplasm collection. Ann. Appl. Biol. 2013, 163, 231-241. [CrossRef]

6. Elia, A.; Santamaria, P. Biodiversity in vegetable crops, a heritage to save: The case of Puglia region. Ital. J. Agron. 2013, 8, 21-34. [CrossRef]

7. Gallitelli, D.; Mascia, T.; Martelli, G.P. Viruses in Artichoke. Adv. Virus Res. 2012, 84, 289-324. [PubMed]

8. Virgin, H.W. The virome in mammalian physiology and disease. Cell 2014, 157, 142-150. [CrossRef] [PubMed]

9. Tollenaere, C.; Susi, H.; Laine, A.L. Evolutionary and epidemiological implications of multiple infection in plants. Trends Plant Sci. 2015, 21, 80-90. [CrossRef] [PubMed]

10. Mascia, T.; Gallitelli, D. Synergies and antagonisms in virus interactions. Plant Sci. 2016, 252, $176-192$. [CrossRef] [PubMed]

11. Minutillo, S.A.; Mascia, T.; Gallitelli, D. A DNA probe mix for the multiplex detection of ten artichoke viruses. Eur. J. Plant Pathol. 2012, 134, 459-465. [CrossRef]

12. Murashige, T.; Skoog, F. A revised medium for rapid growth and bioassays with tobacco tissue cultures. Physiol. Plant. 1962, 15, 473-497. [CrossRef]

13. Fortunato, I.M.; Ruta, C.; Castrignano, A.; Saccardo, A. The effect of mycorrhizal symbiosis on the development of micropropagated artichokes. Sci. Hortic. 2005, 106, 472-483. [CrossRef]

14. Nitsch, J.P.; Nitsch, C. Haploid plants for pollen grains. Science 1969, 63, 85-87. [CrossRef] [PubMed]

15. Lloyd, G.; McCown, B. Commercially-feasible micropropagation of mountain laurel, Kalmia latifolia, by use of shoot-tip culture. Int. Plant Prop. Soc. Proc. 1980, 30, 421-427.

16. Hanssen, I.M.; Lapidot, M.; Thomma, P.H.J.B. Emerging viral diseases of tomato crops. Mol. Plant Microbe Interact. 2010, 23, 539-548. [CrossRef] [PubMed]

17. Hanssen, I.M.; Lapidot, M. Major tomato viruses in the Mediterranean basin. Adv. Virus Res. 2012, 84, 31-66. [PubMed]

18. Vaira, A.M.; Accotto, G.P.; Vecchiati, M.; Bragaloni, M. Tomato infectious chlorosis virus causes leaf yellowing and reddening of tomato in Italy. Phytoparasitica 2002, 30, 290-294. [CrossRef]

19. Davino, S.; Tomassoli, L.; Tiberini, A.; Mondello, V.; Davino, M. Outbreak of tomato infectious chlorosis virus in a relevant artichoke producing area of Sicily. J. Plant Pathol. 2009, 91, S4.57-S4.58.

20. Spanò, R.; Mascia, T.; Minutillo, S.A.; Gallitelli, D. First report of Tomato infectious chlorosis virus from tomato in Apulia, southern Italy. J. Plant Pathol. 2011, 93. [CrossRef]

21. Spanò, R.; Trisciuzzi, N.; Gallitelli, D. Gravi infezioni di Tomato infectious chlorosis virus su pomodoro in Puglia. Prot. Colt. 2015, 4, 43-45.

22. López-Pérez, A.J.; Martínez, J.A. In vitro root induction improvement by culture in darkness for different globe artichoke cultivars. In Vitro Cell. Dev. Biol. Plant 2015, 51, 160-165. [CrossRef]

23. Acquadro, A.; Papanice, M.A.; Lanteri, S.; Bottalico, G.; Portis, E.; Campanale, A.; Finetti-Sialer, M.M.; Mascia, T.; Sumerano, P.; Gallitelli, D. Production and fingerprinting of virus-free clones in a reflowering globe artichoke. Plant Cell Tissue Organ Cult. 2010, 100, 329-337. [CrossRef]

24. Pecaut, P.; Martin, F. Variation occuring after natural and in vitro multiplication of early Mediterranean cultivars of globe artichoke (Cynara scolymus L.). Agronomie 1993, 13, 909-919. [CrossRef]

25. Walkey, D.G.A.; Webb, M.J. Virus in plant apical meristem. J. Gen. Virol. 1968, 3, 311-313. [CrossRef]

26. Appiano, A.; Pennazio, S. Electron microscopy of potato meristem tips infected with potato virus X. J. Gen. Virol. 1972, 14, 273-276. [CrossRef] [PubMed] 
27. Mori, K.; Hosokawa, D. Localization of viruses in apical meristem and production of virus-free plants by means of meristem and tissue culture. Acta Hortic. 1977, 78, 389-396. [CrossRef]

28. Wang, Q.; Cuellar, W.J.; Rajamäki, M.L.; Hirata, Y.; Valkonen, J.P.T. Combined thermotherapy and cryotherapy for efficient virus eradication: Relation of virus distribution, subcellular changes, cell survival and viral RNA degradation in shoot tips. Mol. Plant Pathol. 2008, 9, 237-250. [CrossRef] [PubMed]

29. Goshal, B.; Sanfaçon, H. Symptom recovery in virus-infected plants: Revisiting the role of RNA silencing mechanisms. Virology 2015, 479-480, 167-179. [CrossRef] [PubMed]

30. Santovito, E.; Mascia, T.; Siddiqui, S.A.; Minutillo, S.A.; Valkonen, J.P.T.; Gallitelli, D. Infection cycle of artichoke italian latent virus in tobacco plants: Meristem invasion and recovery from disease symptoms. PLoS ONE 2014, 9. [CrossRef] [PubMed]

31. Walkey, D.G.A.; Cooper, V.C. Effect of temperature on virus eradication and growth of infected tissue cultures. Ann. Appl. Biol. 1975, 80, 185-190. [CrossRef] [PubMed]

32. Cooper, V.C.; Walkey, D.G.A. Thermal inactivation of cherry leaf roll virus in tissue cultures of Nicotiana rustica raised from seeds and meristem tips. Ann. Appl. Biol. 1978, 88, 273-278. [CrossRef]

33. Tang, L.P.; Li, X.M.; Dong, Y.X.; Zhang, X.; Sand Su, Y.H. Microfilament depolymerization is a pre-requisite for stem cell formation during in vitro shoot regeneration in Arabidopsis. Front. Plant. Sci. 2017, 8, 158. [CrossRef] [PubMed]

34. Benoit, H.; Ducreux, G. Etude de quelques aspects de la multiplication végétative in vitro de l'artichaut (Cynara scolymus L.). Agronomie 1981, 1, 225-230. [CrossRef]

35. Morzadec, J.M.; Hourmant, A. In vitro rooting improvement of globe artichoke (cv Camus de Bretagne) by GA3. Sci. Hortic. 1997, 72, 59-62. [CrossRef]

36. Bottalico, G.; Padula, M.; Campanale, A.; Finetti Sialer, M.M.; Saccomanno, F.; Gallitelli, D. Seed transmission of Artichoke Italian latent virus and Artichoke latent virus in globe artichoke. J. Plant Pathol. 2002, 84, 167-168.

37. Massart, S.; Olmos, A.; Jijakli, H.; Candresse, T. Current impact and future directions of high throughput sequencing in plant virus diagnostics. Virus Res. 2014, 188, 90-96. [CrossRef] [PubMed]

38. Massart, S.; Candresse, T.; Gil, J.; Lacomme, C.; Predajna, L.; Ravnikar, M.; Reynard, J.S.; Rumbou, A.; Saldarelli, P.; Škorić Vainio, E.J.; et al. A framework for the evaluation of biosecurity, commercial, regulatory, and scientific impacts of plant viruses and viroids identified by NGS technologies. Front. Microbiol. 2017, 8 , 45. [CrossRef] [PubMed]

39. Wu, Q.; Ding, S.W.; Zhang, Y.; Zhu, S. Identification of viruses and viroids by next-generation sequencing and homology-dependentand homology-independent algorithms. Annu. Rev. Phytopathol. 2015, 53, 425-444. [CrossRef] [PubMed]

40. Martin, R.R.; Constable, F.; Tzanetakis, I.E. Quarantine regulations and the impact of modern detection methods. Annu. Rev. Phytopathol. 2016, 54, 189-205. [CrossRef] [PubMed]

41. Esquinas-Alcázar, J. Protecting crop genetic diversity for food security: Political, ethical and technical challenges. Nat. Rev. Genet. 2005, 6, 946-953. [CrossRef] [PubMed]

(c) 2018 by the authors. Licensee MDPI, Basel, Switzerland. This article is an open access article distributed under the terms and conditions of the Creative Commons Attribution (CC BY) license (http://creativecommons.org/licenses/by/4.0/). 